CRYSTALLOGRAPHIC COMMUNICATIONS

ISSN 2056-9890

Received 12 November 2018

Accepted 19 December 2018

Edited by A. J. Lough, University of Toronto, Canada

Keywords: crystal structure; hydrogen bonding; DFT; Hirshfeld surface analysis.

CCDC reference: 1580647

Supporting information: this article has supporting information at journals.iucr.org/e

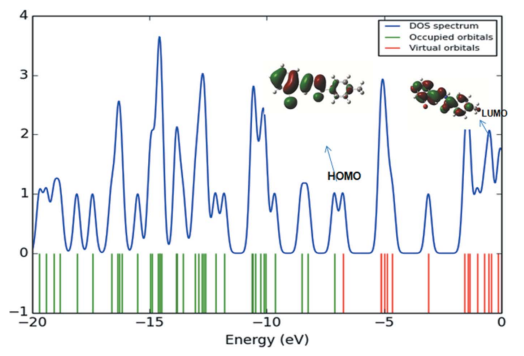

OPEN $\odot$ ACCESS

\section{Synthesis, X-ray crystal structure, Hirshfeld surface analysis and DFT studies of $(E)-N^{\prime}$-(2-bromobenzyl- idene)-4-methylbenzohydrazide}

\author{
Azhagan Ganapathi Anitha, ${ }^{a}$ Chidambaram Arunagiri ${ }^{\mathrm{b} *}$ and Annamalai Subashini ${ }^{\mathrm{c}}$ \\ a PG \& Research Department of Physics, Seethalakshmi Ramaswami College, Tiruchirappalli 620 002, Tamil Nadu, India, \\ ${ }^{\mathbf{b}}$ PG \& Research Department of Physics, Periyar E.V.R. College (Autonomous), Tiruchirappalli 620 023, Tamil Nadu, \\ India, and ${ }^{\mathrm{C}}$ PG \& Research Department of Chemistry, Seethalakshmi Ramaswami College, Tiruchirappalli 620 002, Tamil \\ Nadu, India. *Correspondence e-mail: arunasuba03@gmail.com
}

The title molecule, $\mathrm{C}_{15} \mathrm{H}_{13} \mathrm{BrN}_{2} \mathrm{O}$, displays a trans configuration with respect to the $\mathrm{C}=\mathrm{N}$ double bond. The dihedral angle between the bromo- and methylsubstituted benzene rings is $16.1(3)^{\circ}$. In the crystal, molecules are connected by $\mathrm{N}-\mathrm{H} \cdots \mathrm{O}$ and weak $\mathrm{C}-\mathrm{H} \cdots \mathrm{O}$ hydrogen bonds, forming $R_{2}^{1}(6)$ ring motifs and generating chains along the $a$-axis direction. The optimized structure generated theoretically via density functional theory (DFT) using standard B3LYP functional and 6-311 G(d,p) basis-set calculations renders good support to the experimental data. The HOMO-LUMO behaviour was elucidated to determine the energy gap. The intermolecular interactions were quantified and analysed using Hirshfeld surface analysis.

\section{Chemical_context}

Hydrazones are a class of organic compounds that possess an $R 1 R 2 \mathrm{C}=\mathrm{NNH}_{2}$ structural motif. They are related to ketones and aldehydes in which oxygen has been replaced with an $\mathrm{NNH}_{2}$ group (Rollas \& Küçükgüzel, 2007). Azomethines, $-\mathrm{NHN}=\mathrm{CH}-$, constitute an important class of compounds for new drug development. The reaction of a hydrazine or hydrazide with aldehydes and ketones yields hydrazones. Hydrazones are important in drug design as they act as ligands for metal complexes, organocatalysis and the synthesis of organic compounds. The $\mathrm{C}=\mathrm{N}$ bond of the hydrazone and the terminal nitrogen atom containing a lone pair of electron is responsible for the physical and chemical properties. The $\mathrm{C}$ atom in the hydrazone unit has both electrophilic and nucleophilic character and both the $\mathrm{N}$ atoms are nucleophilic, although the amino-type nitrogen is more reactive. As a result of these properties, hydrazones are widely used in organic synthesis. Owing to their ease of preparation and diverse pharmacological potential, much work on hydrazones has been carried out by medicinal chemists to develop agents with better activity and low toxicity profiles. Hydrazones are known to possess diverse biological activities such as antimicrobial, anti-inflammatory, anticancer and antimalarial (Yousef et al., 2003; Trepanier et al., 1966) and have been evaluated for inhibition of PDE10A, a phosphodiesterase responsible for neurological and psychological disorders such as Parkinson's, schizophrenia and Huntington's disease (Gage et al., 2011). The anticonvulsant potential of some hydrazone derivatives having long duration and rapid onset of action have been reported (Kaushik et al., 2010), as has their anti-depressant activity (de Oliveira et al., 2011). 
Schiff bases are used widely in the field of coordination chemistry and have interesting properties (Morshedi et al., 2009; Zhou et al., 2006; Khanmohammadi et al., 2009). These compounds are synthesized by condensation of carbonyl compounds with amines (van den Ancker et al., 2006; Hamaker et al., 2010). In addition, free Schiff base compounds are reported to possess antimicrobial (Aslantas et al., 2009) and non-linear optical (Karakaş et al., 2008) properties. Our previous work on (E)-4-bromo- $N^{\prime}$-(2,4-dihydroxybenzylidene)benzohydrazide and (E)-4-toluic - $N^{\prime}$-(2,4-dihydroxybenzylidene)benzohydrazide have been recently reported (Arunagiri et al., 2018a,b). This work has been a guide for the development of the new Schiff base title compound, which possesses electronic and non-linear properties. As part of our interest in the identification of bioactive compounds, we report herein on its crystal structure.

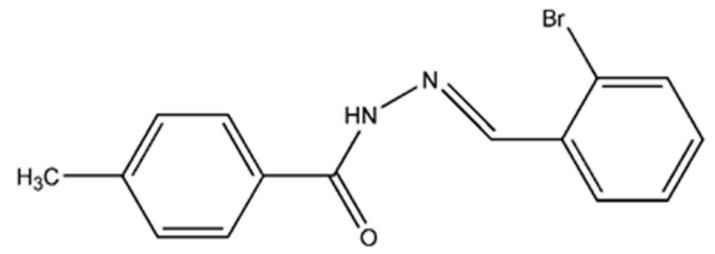

\section{Structural commentary}

The molecular structure of the title compound is shown in Fig. 1(a). The molecule adopts an $(E)$ configuration across the $\mathrm{C}=\mathrm{N}$ bond, joining the hydrazide group and the benzene ring. In the crystal, the dihedral angle between the bromo- and methyl-substituted benzene rings is $16.1(3)^{\circ}$. The structure was optimized with the Gaussian09W software (Frisch et al., 2009) using the DFT-B3LYP/6-311G(d,p) method, providing
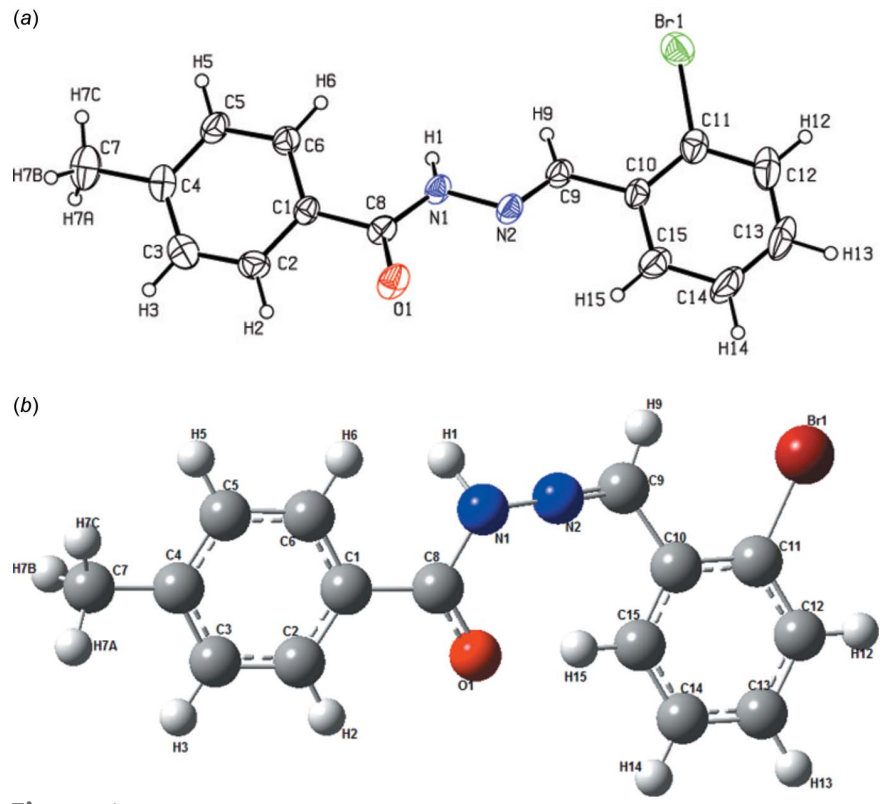

Figure 1

(a) The molecular structure of the title compound, with displacement ellipsoids drawn at the $50 \%$ probability level. (b) The optimized structure of the title compound.
Table 1

Selected geometric parameters $\left(\AA{ }^{\circ}\right)$ for the experimental and DFT structures.

\begin{tabular}{lcc}
\hline & XRD & DFT \\
\hline Br1-C11 & $1.891(6)$ & 1.925 \\
O1-C8 & $1.225(6)$ & 1.219 \\
N1-N2 & $1.379(5)$ & 1.364 \\
N1-C8 & $1.351(6)$ & 1.383 \\
N2-C9 & $1.270(6)$ & 1.285 \\
N1-H1 & $0.837(19)$ & 1.006 \\
C1-C8 & $1.485(6)$ & 1.501 \\
C9-C10 & $1.470(8)$ & 1.470 \\
C9-H9 & 0.930 & 1.082 \\
& & \\
N2-N1-C8 & $119.2(4)$ & 120.00 \\
C8-N1-H1 & $123(4)$ & 117.84 \\
N2-N1-H1 & $117(4)$ & 111.31 \\
N1-C8-C1 & $116.6(4)$ & 114.46 \\
O1-C8-C1 & $121.6(4)$ & 122.20 \\
O1-C8-N1 & $121.7(4)$ & 123.33 \\
N2-C9-C10 & $120.1(4)$ & 118.62 \\
N2-C9-H9 & 120.00 & 122.79 \\
& & \\
C8-N1-N2-C9 & $-173.3(5)$ & -179.68 \\
N2-N1-C8-O1 & $-3.5(7)$ & 2.54 \\
N2-N1-C8-C1 & $174.64)$ & -178.45 \\
C2-C1-C8-O1 & $24.6(7)$ & 22.94 \\
C2-C1-C8-N1 & $-153.6(5)$ & -156.06 \\
N2-C9-C10-C11 & $161.4(5)$ & -0.14 \\
N2-C9-C10-C15 & $-19.2(7)$ &
\end{tabular}

Table 2

Hydrogen-bond geometry $\left(\AA,{ }^{\circ}\right)$.

\begin{tabular}{lllll}
\hline$D-\mathrm{H} \cdots A$ & $D-\mathrm{H}$ & $\mathrm{H} \cdots A$ & $D \cdots A$ & $D-\mathrm{H} \cdots A$ \\
\hline $\mathrm{N} 1-\mathrm{H} 1 \cdots \mathrm{O} 1^{\mathrm{i}}$ & $0.84(3)$ & $1.96(3)$ & $2.785(5)$ & $167(5)$ \\
$\mathrm{C} 9-\mathrm{H} 9 \cdots{ }^{\mathrm{i}}$ & 0.93 & 2.38 & $3.166(6)$ & 142 \\
\hline
\end{tabular}

Symmetry code: (i) $x-\frac{1}{2},-y+\frac{1}{2}, z$.

information about the geometry of the molecule. The optimized structure is shown in Fig. 1(b). The geometrical parameters (Table 1) are mostly within normal ranges, the slight deviations of the theoretical values from those determined experimentally are due to the fact that the optimization is performed in isolated conditions, whereas the crystal environment and hydrogen-bonding interactions affect the results of the X-ray structure (Zainuri et al., 2017).

The hydrazide unit $(\mathrm{N} 1 / \mathrm{N} 2 / \mathrm{C} 1 / \mathrm{C} 8-\mathrm{C} 10)$ is essentially planar, with a maximum deviation from the least-squares plane of 0.099 (4) $\AA$ for atom $\mathrm{C} 10$. The $\mathrm{O} 1=\mathrm{C} 8$ bond length [1.225 (6) and $1.219 \AA$ for XRD and B3LYP, respectively] indicates single-bond character. The N1-N2 bond length [1.379 (5) $\AA$ for XRD and $1.364 \AA$ for B3LYP] is in good agreement with other experimental values (Sivajeyanthi et al., 2017). The $\mathrm{C}-\mathrm{N}$ bond lengths range from a typical single bond $[\mathrm{C} 8-\mathrm{N} 1=1.351(6) \AA]$ to a double bond $[\mathrm{C} 9=\mathrm{N} 2=$ 1.270 (6) Å (Sivajeyanthi et al., 2017; Arunagiri et al., 2018a,b).

\section{Supramolecular features}

In the crystal, $\mathrm{N} 1-\mathrm{H} 1 \cdots \mathrm{O} 1^{\mathrm{i}}$ and $\mathrm{C} 9-\mathrm{H} 9 \cdots \mathrm{O} 1^{\mathrm{i}}$ hydrogen bonds (Table 2) connect symmetry-related molecules through 


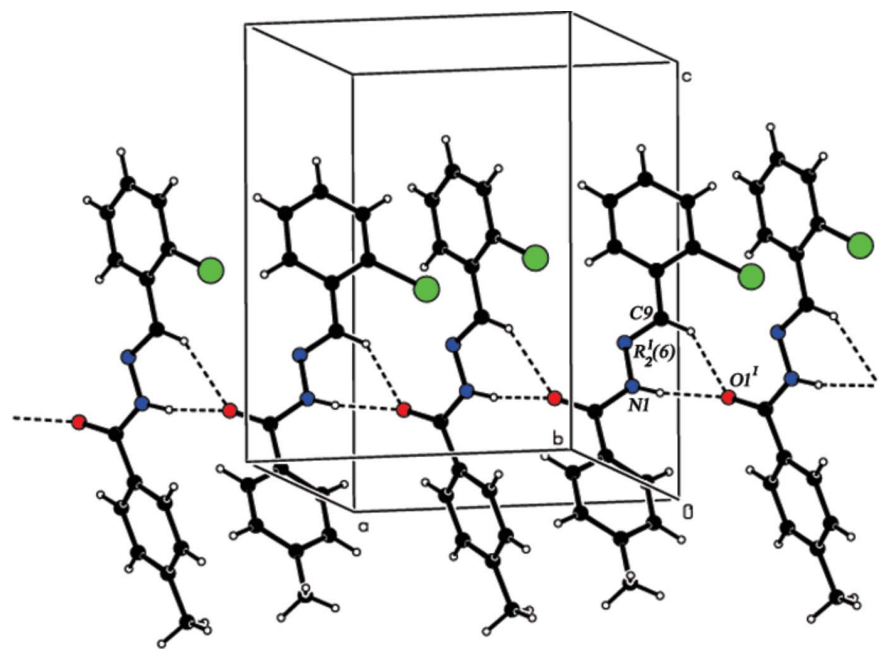

Figure 2

Part of the crystal structure with hydrogen bonds shown as dashed lines.

classical $\mathrm{N}-\mathrm{H} \cdots \mathrm{O}$ and weak $\mathrm{C}-\mathrm{H} \cdots \mathrm{O}$ hydrogen bonds, forming $R_{2}^{1}(6)$ ring motifs and generating [100] chains (Fig. 2).

\section{Hirshfeld surface analysis}

Hirshfeld surface analysis (McKinnon et al., 2007; Spackman \& Jayatilaka, 2009) along with decomposed 2D fingerprint plots (Spackman \& McKinnon, 2002; McKinnon et al., 2004, 2007) mapped over $d_{\text {norm }}$, shape-index and curvedness were used to visualize and quantify the intermolecular interactions. The Hirshfeld surface (HS) and fingerprint plots were generated based on the $d_{\mathrm{i}}$ and $d_{\mathrm{e}}$ distances using Crystal Explorer3.1 (Wolff et al., 2012) where $d_{\mathrm{i}}$ is the distance from the nearest atom inside the surface, while $d_{\mathrm{e}}$ is the distance from the HS to the nearest atom outside the surface. In the $d_{\text {norm }}$ surfaces, large circular depressions (deep red) are the indicators of hydrogen-bonding contacts whereas other visible spots are due to $\mathrm{H} \cdots \mathrm{H}$ contacts. The dominant $\mathrm{H} \cdots \mathrm{O}$ interaction in the title compound is evident as a bright-red area in Fig. 3 while the light-red spots are due to $\mathrm{N}-\mathrm{H} \cdots \mathrm{O}$ and $\mathrm{C}-\mathrm{H} \cdots \mathrm{O}$ interactions. The shape-index surface [Fig. 4(a)] conveys information about each donor-acceptor pair and while the

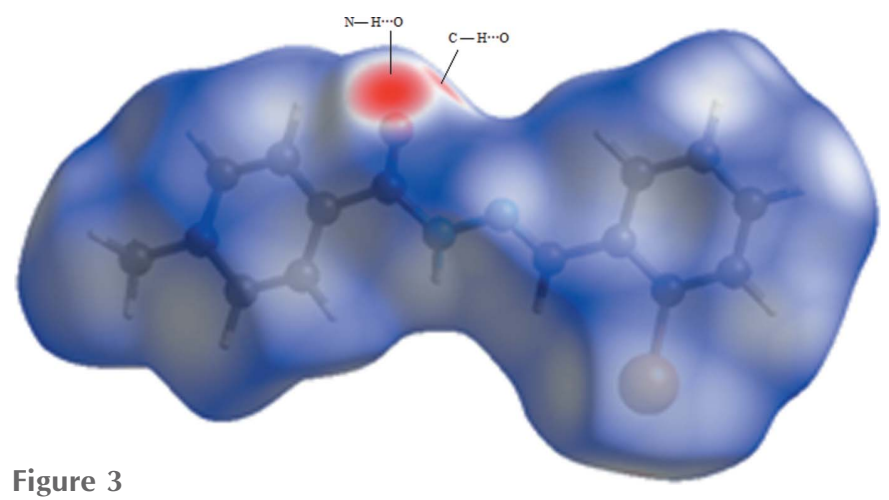

Figure 3

The three-dimensional $d_{n o r m}$ surface of the title compound. add contouring levels

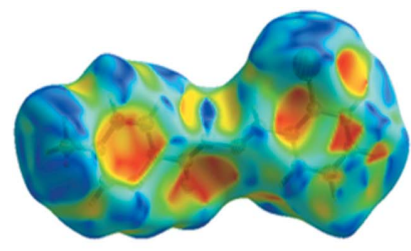

a

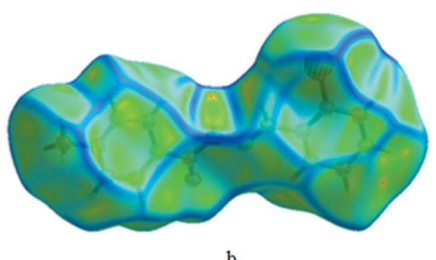

b
Figure 4

Hirshfeld surfaces mapped over $(a)$ shape-index and $(b)$ curvedness for the title compound.

curvedness surface [Fig. 4(b)] is effectively divided into sets of patches, respectively. The tiny extent of area and light colour on the surface indicates weaker and longer contacts other than hydrogen bonds. The 2D fingerprint plots in Fig. 5 shows the relative contributions from the various intermolecular contacts $(\mathrm{O} \cdots \mathrm{H}, \mathrm{H} \cdots \mathrm{H}, \mathrm{C} \cdots \mathrm{H}, \mathrm{C} \cdots \mathrm{C}, \mathrm{N} \cdots \mathrm{H}, \mathrm{N} \cdots \mathrm{N}, \mathrm{O} \cdot \mathrm{Br}$ and $\mathrm{C} . \mathrm{Br})$ in the crystal structure. The $\mathrm{H} \cdot \mathrm{H}$ contacts $(36 \%)$ make the largest contribution, followed by $\mathrm{C} \cdots \mathrm{H} / \mathrm{H} \cdots \mathrm{C}$ $(28.2 \%), \mathrm{O} \cdots \mathrm{H} / \mathrm{H} \cdots \mathrm{O}(10.2 \%)$ and $\mathrm{N} \cdots \mathrm{H} / \mathrm{H} \cdots \mathrm{N}(7.5 \%)$, the latter interactions being represented by blue spikes on both sides at the bottom of the plot.

\section{Frontier molecular orbitals and Molecular electrostatic potential analysis}

The highest-occupied molecular orbital (HOMO), which acts as an electron donor, and the lowest-unoccupied molecular orbital (LUMO), which acts as an electron acceptor, are very important parameters for quantum chemistry. If the energy gap is small, then the molecule is highly polarizable and has

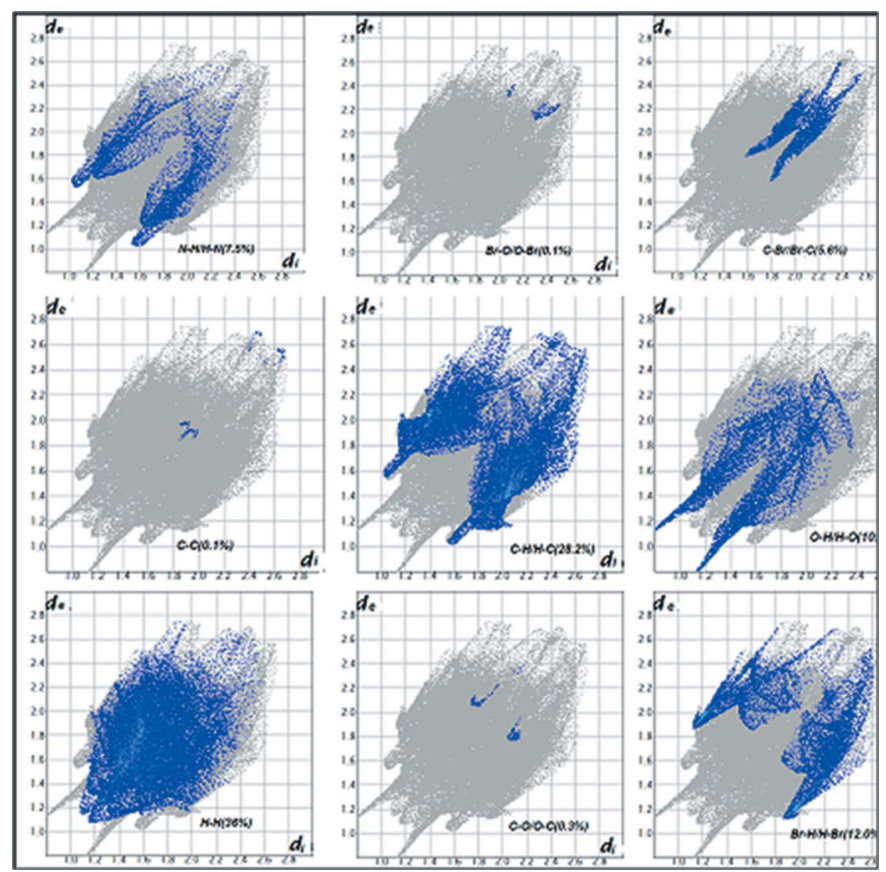

Figure 5

Two-dimensional fingerprint plots with the relative contributions of the various interactions. 

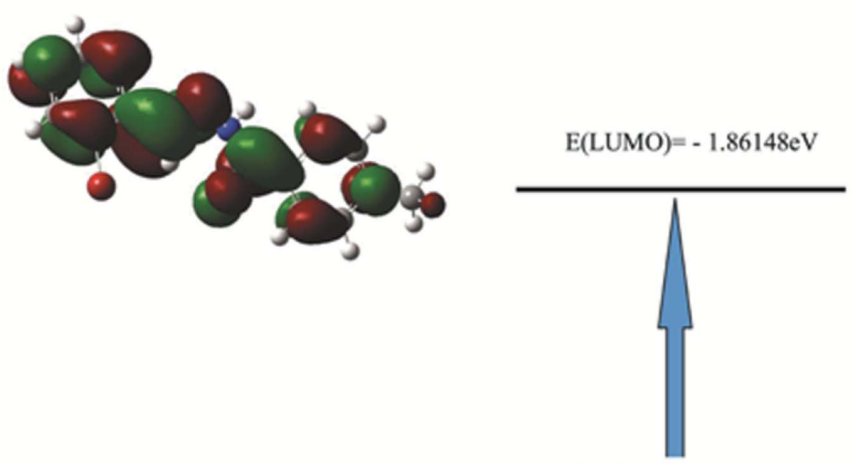

$\mathrm{E}(\mathrm{HOMO})-\mathrm{E}(\mathrm{LUMO})=4.42 \mathrm{eV}$

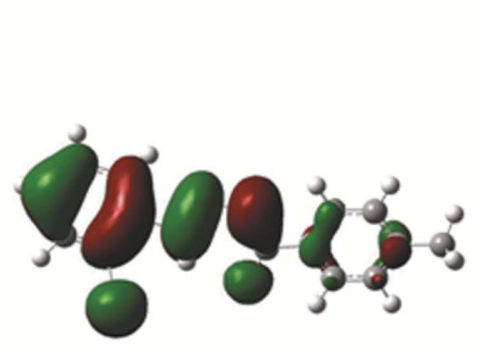

$\mathrm{E}(\mathrm{HOMO})=-6.27941 \mathrm{eV}$

Figure 6

The energy band gap of the compound.

high chemical reactivity. The energy levels were computed by the DFTB3LYP/6-311G(d,p) method (Becke et al., 1993) as implemented in GAUSSIAN09W (Frisch et al., 2009). The electron transition from the HOMO to the LUMO energy level is shown in Fig. 6. The molecular orbital of HOMO contain both $\sigma$ and $\pi$ electron-density character, whereas the LUMO is mainly composed of $\pi$-orbital density. The energy band gap $(\Delta E)$ of the molecule is about $4.42 \mathrm{eV}$.

The Gauss-Sum2.2 program (O'Boyle et al., 2008) was used to calculate group contributions to the molecular orbitals (HOMO and LUMO) and prepare the density of states (DOS) spectrum shown in Fig. 7. The DOS spectrum was formed by convoluting the molecular orbital information with GAUSSIAN curves of unit height. The green and red lines in the DOS spectrum indicate the HOMO and LUMO levels. The

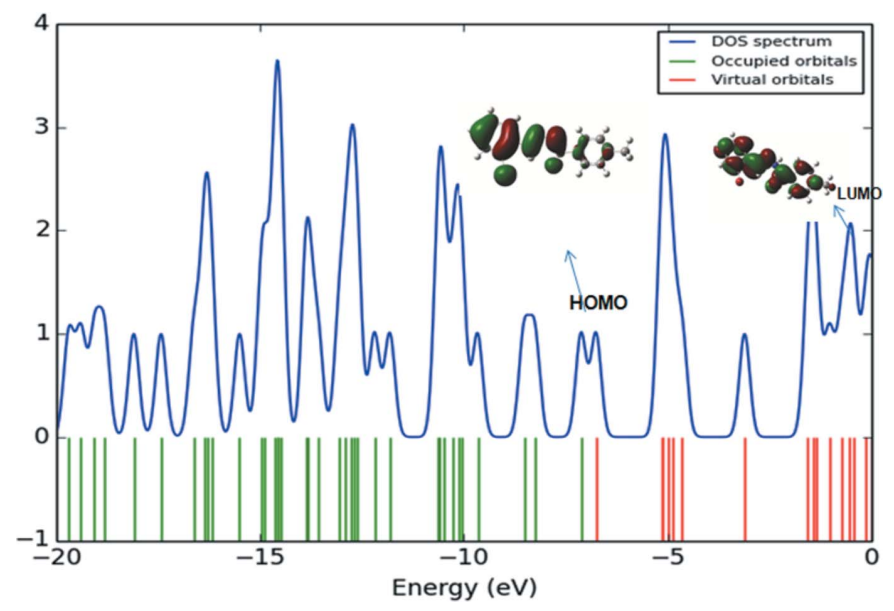

Figure 7

The density of states (DOS) spectrum of the compound.

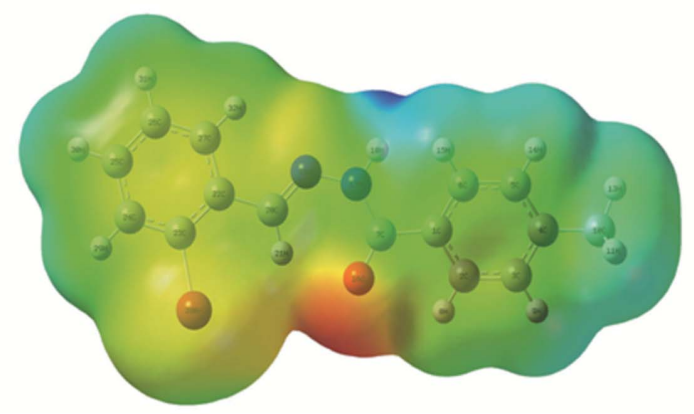

Figure 8

The molecular electrostatic potential map for the title compound.

DOS spectrum supports the energy gap calculated by HOMO-LUMO analysis. A molecule with a large energy gap is described as hard while one having a small energy gap is known as a soft molecule. Hard molecules are not more polarizable than the soft ones because they require immense excitation energy (Karabacak \& Yilan, 2012).

The molecular electrostatic potential is related to the electron density and molecular electrostatic potential (MESP) maps are very useful descriptors for understanding reactive sites for electrophilic and nucleophilic reactions as well as hydrogen-bonding interactions (Sebastian \& Sundaraganesan, 2010; Luque et al., 2000). Different values of the electrostatic potential are represented by different colours: red represents regions of the most electronegative electrostatic potential, blue represents regions of the most positive electrostatic potential and green represents regions of zero potential. The potential increases in the following order: red $<$ orange $<$ yellow $<$ green $<$ blue. Herein, MEP was calculated at the DFT-B3LYP/6-311(d,p) level of theory that was used for optimization. The MESP map for the title molecule is shown in Fig. 8 with a colour range from -0.053 (red) to 0.053 a.u. (blue). The most electrostatically positive region (blue colour) is located in the molecular plane ( $\mathrm{N}$-bonded hydrogen atoms of toluic hydrazide), thus explaining $\mathrm{N} 1-\mathrm{H} 1 \cdots \mathrm{O} 1^{\mathrm{i}}$ hydrogen bond observed in the crystal structure. The map clearly shows that the electron-rich (red) region is spread around the carbonyl oxygen atom whereas the hydrogen atom attached to nitrogen is positively charged (blue).

\section{Database survey}

A search of the Cambridge Structural Database (Version 5.39, last update November 2018; Groom et al., 2016) revealed closely related compounds that differ in the donor substituents: $\quad N^{\prime}$-(4-chlorobenzylidene)-2-hydroxybenzohydrazide (Zhang et al., 2009), (E)-N'-[(pyridin-2-yl)methylene]benzohydrazide (Ramesh Babu et al., 2014), (E)- $N^{\prime}$-(4-methoxybenzylidene)pyridine-3-carbohydrazide dihydrate (Govindarasu et al., 2015), (E)-4-bromo- $N^{\prime}$-(4-methoxybenzylidene)benzohydrazide(Balasubramani et al., 2018), (E)-3-(1H-indol- 

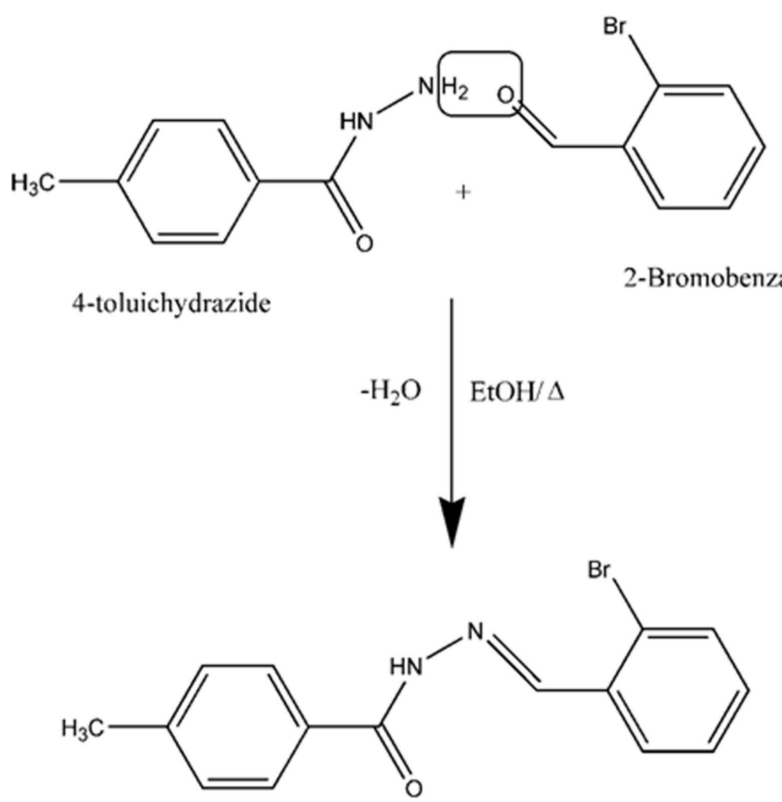

Figure 9

Reaction scheme.

2-yl)-1-(4-nitrophenyl)prop-2-en-1-one hemihydrate (Zaini et al., 2018); (E)-4-bromo- $N^{\prime}$-(2,4-dihydroxybenzylidene)benzohydrazide and (E)-4-toluic- $N^{\prime}$-(2,4-dihydroxybenzylidene)benzohydrazide (Arunagiri et al., 2018a,b). In our studies of analagous hydrazide dervatives (with $\mathrm{Cl}$ or $\mathrm{Br}$ replacing the methyl group of the title compound, we have observed similar types of Intramolecular $S(6)$ and intermolecular $\mathrm{N}-\mathrm{H} \cdots \mathrm{O}$ hydrogen bonds (between the amide hydrogen and the carbonyl oxygen atoms).

\section{Synthesis and crystallization}

The title compound was synthesized by the condensation of 4toluic hydrazide and 2-bromobenzaldehyde (Fig. 9). An ethanol solution $(10 \mathrm{ml})$ of 4 -toluic hydrazide $(0.25 \mathrm{~mol})$ was mixed with ethanol solution of 2-bromobenzaldehyde $(10 \mathrm{ml}$, $0.25 \mathrm{~mol}$ ) and the reaction mixture was heated at $323 \mathrm{~K}$ for half an hour with constant stirring before being was filtered and kept for crystallization. After a period of one week, brown block-shaped crystals of the title compound were obtained.

\section{X-ray crystallography and refinement}

Crystal data, data collection and structure refinement details are summarized in Table 3. The hydrogen atom on N1 (H1) was located in a difference-Fourier map and freely refined. Cbound hydrogen atoms were placed in calculated positions $(\mathrm{C}-\mathrm{H}=0.93-0.96 \AA)$ and refined as riding with $U_{\text {iso }}(\mathrm{H})$ $=1.2 U_{\mathrm{eq}}(\mathrm{C})$ or $1.5 U_{\mathrm{eq}}(\mathrm{C}$-methyl $)$.

\section{Funding information}

AGA thanks the University Grants Commission (UGC), New Delhi, India, for the award of a Research Fellowship under the Faculty Development Programme (FDP).
Table 3

Experimental details.

Crystal data

Chemical formula

$M_{\mathrm{r}}$

Crystal system, space group

Temperature (K)

$a, b, c(\AA)$

$V\left(\AA^{3}\right)$

$Z$

Radiation type

$\mu\left(\mathrm{mm}^{-1}\right)$

Crystal size (mm)

$\mathrm{C}_{15} \mathrm{H}_{13} \mathrm{BrN}_{2} \mathrm{O}$

317.18

Orthorhombic, Pna2 1

296

9.6002 (10), 11.5584 (13), $12.5823(12)$

$1396.2(3)$

Mo $K \alpha$

2.94

$0.30 \times 0.25 \times 0.20$

Data collection

Diffractometer

Absorption correction

$T_{\min }, T_{\max }$

No. of measured, independent and observed $[I>2 \sigma(I)]$ reflections

$R_{\text {in }}$

$(\sin \theta / \lambda)_{\max }\left(\AA^{-1}\right)$

Bruker Kappa APEXII CCD Multi-scan (SADABS; Bruker, 2004)

$0.473,0.591$

17816, 2744, 1837

0.035

0.617

\section{Refinement}

$R\left[F^{2}>2 \sigma\left(F^{2}\right)\right], w R\left(F^{2}\right), S$

No. of reflections

No. of parameters

No. of restraints

$\mathrm{H}$-atom treatment

$0.037,0.097,1.10$
2744
176
2
$\mathrm{H}$ atoms treated by a mixture of
$\quad$ independent and constrained
$\quad$ refinement
$0.42,-0.47$

$\Delta \rho_{\max }, \Delta \rho_{\min }\left(\mathrm{e} \AA^{-3}\right)$

$0.42,-0.47$

Computer programs: APEX2, SAINT and XPREP (Bruker, 2004), SIR97 (Altomare et al., 1999), SHELXLO14 (Sheldrick, 2015) and ORTEP-3 for Windows (Farrugia, 2012).

\section{References}

Altomare, A., Burla, M. C., Camalli, M., Cascarano, G. L., Giacovazzo, C., Guagliardi, A., Moliterni, A. G. G., Polidori, G. \& Spagna, R. (1999). J. Appl. Cryst. 32, 115-119.

Ancker, T. R. van den, Cave, G. W. V. \& Raston, C. L. (2006). Green Chem. 8, 50-53.

Arunagiri, C., Anitha, A. G., Subashini, A. \& Selvakumar, S. (2018a). J. Mol. Struct. 1163, 368-378.

Arunagiri, C., Anitha, A. G., Subashini, A., Selvakumar, S. \& Lokanath, N. K. (2018b). Chem. Data Collect. 17-18, 169-177.

Aslantaş, M., Kendi, E., Demir, N., Şabik, A. E., Tümer, M. \& Kertmen, M. (2009). Spectrochim. Acta A Mol. Biomol. Spectrosc. 74, 617-624.

Balasubramani, K., Premkumar, G., Sivajeyanthi, P., Jeevaraj, M., Edison, B. \& Swu, T. (2018). Acta Cryst. E74, 1500-1503.

Becke, A. (1993). J. Chem. Phys. 98, 5648-5652.

Bruker (2004). SAINT, APEX2, XPREP and SADABS. Bruker AXS Inc., Madison, Wisconsin, USA.

Farrugia, L. J. (2012). J. Appl. Cryst. 45, 849-854.

Frisch, M. J., et al. (2009). GAUSSIAN09. Gaussian Inc., Wallingford, CT, USA.

Gage, J. L., Onrust, R., Johnston, D., Osnowski, A., MacDonald, W., Mitchell, L., Ürögdi, L., Rohde, A., Harbol, K., Gragerov, S., Dormán, G., Wheeler, T., Florio, V. \& Cutshall, N. S. (2011). Bioorg. Med. Chem. Lett. 21, 4155-4159.

Govindarasu, K., Kavitha, E., Sundaraganesan, N., Suresh, M. \& Syed Ali Padusha, M. (2015). Spectrochim. Acta A, 135, 1123-1136.

Groom, C. R., Bruno, I. J., Lightfoot, M. P. \& Ward, S. C. (2016). Acta Cryst. B72, 171-179.

Hamaker, C. G., Maryashina, O. S., Daley, D. K. \& Wadler, A. L. (2010). J. Chem. Crystallogr. 40, 34-39. 
Karabacak, M. \& Yilan, E. (2012). Spectrochim. Acta A, 87, 273285.

Karakaş, A., Ünver, H. \& Elmali, A. (2008). J. Mol. Struct. 877, 152157.

Kaushik, D., Khan, S. A., Chawla, G. \& Kumar, S. (2010). Eur. J. Med. Chem. 45, 3943-3949.

Khanmohammadi, H., Salehifard, M. \& Abnosi, M. H. (2009). J. Iran. Chem. Soc. 6, 300-309.

Luque, E. J., López, J. M. \& Orozco, M. (2000). Theor. Chem. Acc. 103, 343-345.

McKinnon, J. J., Jayatilaka, D. \& Spackman, M. A. (2007). Chem. Commun. 3814-3816.

McKinnon, J. J., Spackman, M. A. \& Mitchell, A. S. (2004). Acta Cryst. B60, 627-668.

Morshedi, M., Amirnasr, M., Triki, S. \& Khalaji, A. D. (2009). Inorg. Chim. Acta, 362, 1637-1640.

O'Boyle, N. M., Tenderholt, A. L. \& Langner, K. M. (2008). J. Comput. Chem. 29, 839-845.

Oliveira, K. N. de, Costa, P., Santin, J. R., Mazzambani, L., Bürger, C., Mora, C., Nunes, R. J. \& de Souza, M. M. (2011). Bioorg. Med. Chem. 19, 4295-4306.

Ramesh Babu, N., Subashchandrabose, S., Padusha, M. S. A., Saleem, H., Manivannan, V. \& Erdoğdu, Y. (2014). J. Mol. Struct. 1072, 8493.

Rollas, S. \& Küçükgüzel, G. S. (2007). Molecules, 12, 1910-1939.
Sebastian, S. \& Sundaraganesan, N. (2010). Spectrochim. Acta A, 75, 941-952.

Sheldrick, G. M. (2015). Acta Cryst. C71, 3-8.

Sivajeyanthi, P., Jeevaraj, M., Balasubramani, K., Viswanathan, V. \& Velmurugan, D. (2017). Chem. Data Collect. 11-12, 220-231.

Spackman, M. A. \& Jayatilaka, D. (2009). CrystEngComm, 11, 1932.

Spackman, M. A. \& McKinnon, J. J. (2002). CrystEngComm, 4, 378392.

Trepanier, D. L., Wagner, E. R., Harris, G. \& Rudzik, A. D. (1966). J. Med. Chem. 9, 881-885.

Wolff, S. K., Grimwood, D. J., McKinnon, J. J., Turner, M. J., Jayatilaka, D. \& Spackman, M. A. (2012). CrystalExplorer3.1. University of Western Australia, Perth, Australia.

Yousef, E. A., Zaki, A. \& Megahed, M. G. (2003). Heterocycl. Commun. 9, 293-298.

Zaini, M. F., Razak, I. A., Khairul, W. M. \& Arshad, S. (2018). Acta Cryst. E74, 1589-1594.

Zainuri, D. A., Arshad, S., Khalib, N. C., Razak, A. I., Pillai, R. R., Sulaiman, F., Hashim, N. S., Ooi, K. L., Armaković, S., Armaković, S. J., Panicker, Y. \& Van Alsenoy, C. (2017). J. Mol. Struct. 1128, 520-533.

Zhang, S.-P., Qiao, R. \& Shao, S.-C. (2009). Acta Cryst. E65, o84.

Zhou, X. H., Wu, T. \& Li, D. (2006). Inorg. Chim. Acta, 359, 14421448. 


\section{supporting information}

Acta Cryst. (2019). E75, 109-114 [https://doi.org/10.1107/S2056989018017978]

Synthesis, X-ray crystal structure, Hirshfeld surface analysis and DFT studies of (E)-N'-(2-bromobenzylidene)-4-methylbenzohydrazide

\section{Azhagan Ganapathi Anitha, Chidambaram Arunagiri and Annamalai Subashini}

Computing details

Data collection: APEX2 (Bruker, 2004); cell refinement: APEX2 and SAINT (Bruker, 2004); data reduction: SAINT and XPREP (Bruker, 2004); program(s) used to solve structure: SIR97 (Altomare et al., 1999); program(s) used to refine structure: SHELXL014 (Sheldrick, 2015); molecular graphics: ORTEP-3 for Windows (Farrugia, 2012); software used to prepare material for publication: SHELXL2014 (Sheldrick, 2015).

(E)-4-Methyl-N'-(2-bromobenzylidene)benzohydrazide

Crystal data

$\mathrm{C}_{15} \mathrm{H}_{13} \mathrm{BrN}_{2} \mathrm{O}$

$M_{r}=317.18$

Orthorhombic, Pna2 $_{1}$

Hall symbol: P 2c $-2 \mathrm{n}$

$a=9.6002(10) \AA$

$b=11.5584$ (13) $\AA$

$c=12.5823(12) \AA$

$V=1396.2(3) \AA^{3}$

$Z=4$

\section{Data collection}

Bruker Kappa APEXII CCD diffractometer

Radiation source: fine-focus sealed tube Graphite monochromator $\omega$ and $\varphi$ scan

Absorption correction: multi-scan

(SADABS; Bruker, 2004)

$T_{\min }=0.473, T_{\max }=0.591$

\section{Refinement}

Refinement on $F^{2}$

Least-squares matrix: full

$R\left[F^{2}>2 \sigma\left(F^{2}\right)\right]=0.037$

$w R\left(F^{2}\right)=0.097$

$S=1.10$

2744 reflections

176 parameters

2 restraints
$F(000)=640$

$D_{\mathrm{x}}=1.509 \mathrm{Mg} \mathrm{m}^{-3}$

Mo $K \alpha$ radiation, $\lambda=0.71073 \AA$

Cell parameters from 6594 reflections

$\theta=2.4-26.0^{\circ}$

$\mu=2.94 \mathrm{~mm}^{-1}$

$T=296 \mathrm{~K}$

Block, brown

$0.30 \times 0.25 \times 0.20 \mathrm{~mm}$

17816 measured reflections

2744 independent reflections

1837 reflections with $I>2 \sigma(I)$

$R_{\text {int }}=0.035$

$\theta_{\max }=26.0^{\circ}, \theta_{\min }=2.4^{\circ}$

$h=-11 \rightarrow 11$

$k=-14 \rightarrow 14$

$l=-15 \rightarrow 15$

Primary atom site location: structure-invariant direct methods

Secondary atom site location: difference Fourier map

Hydrogen site location: inferred from neighbouring sites

$\mathrm{H}$ atoms treated by a mixture of independent and constrained refinement 
$w=1 /\left[\sigma^{2}\left(F_{\mathrm{o}}^{2}\right)+(0.0208 P)^{2}+2.2419 P\right]$

where $P=\left(F_{\mathrm{o}}^{2}+2 F_{\mathrm{c}}^{2}\right) / 3$

$(\Delta / \sigma)_{\max }<0.001$

$$
\Delta \rho_{\max }=0.42 \mathrm{e} \AA^{-3}
$$

$\Delta \rho_{\min }=-0.47 \mathrm{e} \AA^{-3}$

\section{Special details}

Geometry. All esds (except the esd in the dihedral angle between two 1.s. planes) are estimated using the full covariance matrix. The cell esds are taken into account individually in the estimation of esds in distances, angles and torsion angles; correlations between esds in cell parameters are only used when they are defined by crystal symmetry. An approximate (isotropic) treatment of cell esds is used for estimating esds involving 1.s. planes.

Refinement. Refinement of $\mathrm{F}^{2}$ against ALL reflections. The weighted $\mathrm{R}$-factor $\mathrm{wR}$ and goodness of fit $\mathrm{S}$ are based on $\mathrm{F}^{2}$, conventional R-factors $R$ are based on $F$, with $F$ set to zero for negative $F^{2}$. The threshold expression of $F^{2}>2$ sigma $\left(F^{2}\right)$ is used only for calculating R-factors(gt) etc. and is not relevant to the choice of reflections for refinement. R-factors based on $\mathrm{F}^{2}$ are statistically about twice as large as those based on F, and R-factors based on ALL data will be even larger.

Fractional atomic coordinates and isotropic or equivalent isotropic displacement parameters $\left(\AA^{2}\right)$

\begin{tabular}{|c|c|c|c|c|}
\hline & $x$ & $y$ & $z$ & $U_{\text {iso }} * / U_{\text {eq }}$ \\
\hline Br1 & $0.27412(5)$ & $0.49846(5)$ & $0.50267(12)$ & $0.06555(18)$ \\
\hline O1 & 0.7807 (3) & $0.1961(4)$ & $0.2048(3)$ & $0.0633(11)$ \\
\hline N1 & $0.5643(4)$ & $0.2641(4)$ & $0.2337(3)$ & $0.0430(10)$ \\
\hline N2 & $0.5965(5)$ & $0.2925(4)$ & 0.3373 & $0.0464(11)$ \\
\hline $\mathrm{C} 1$ & $0.6174(5)$ & $0.1750(4)$ & 0.0649 & $0.0390(10)$ \\
\hline $\mathrm{C} 2$ & $0.6886(5)$ & $0.0846(4)$ & $0.0191(5)$ & $0.0529(14)$ \\
\hline $\mathrm{H} 2$ & 0.7632 & 0.0514 & 0.0551 & $0.064^{*}$ \\
\hline $\mathrm{C} 3$ & $0.6512(7)$ & $0.0427(5)$ & $-0.0791(5)$ & $0.0632(15)$ \\
\hline H3 & 0.7000 & -0.0193 & -0.1080 & $0.076^{*}$ \\
\hline $\mathrm{C} 4$ & $0.5433(6)$ & $0.0907(5)$ & $-0.1352(4)$ & $0.0546(14)$ \\
\hline $\mathrm{C} 5$ & $0.4721(6)$ & $0.1827(5)$ & $-0.0902(4)$ & $0.0526(13)$ \\
\hline H5 & 0.3987 & 0.2165 & -0.1271 & $0.063 *$ \\
\hline C6 & $0.5085(4)$ & $0.2251(4)$ & 0.0089 & $0.0446(10)$ \\
\hline H6 & 0.4599 & 0.2872 & 0.0378 & $0.054^{*}$ \\
\hline $\mathrm{C} 7$ & 0.4998 (11) & $0.0447(6)$ & $-0.2424(6)$ & $0.0834(19)$ \\
\hline $\mathrm{H} 7 \mathrm{C}$ & 0.4230 & 0.0894 & -0.2689 & $0.125^{*}$ \\
\hline H7A & 0.4723 & -0.0348 & -0.2356 & $0.125^{*}$ \\
\hline H7B & 0.5766 & 0.0503 & -0.2910 & $0.125^{*}$ \\
\hline $\mathrm{C} 8$ & $0.6621(5)$ & $0.2130(4)$ & $0.1724(4)$ & $0.0429(11)$ \\
\hline C9 & $0.4964(5)$ & $0.3296(4)$ & $0.3937(4)$ & $0.0446(12)$ \\
\hline H9 & 0.4093 & 0.3413 & 0.3632 & $0.053 *$ \\
\hline $\mathrm{C} 10$ & $0.5182(5)$ & 0.3543 & $0.5071(5)$ & $0.0435(10)$ \\
\hline $\mathrm{C} 11$ & $0.4290(6)$ & $0.4236(4)$ & $0.5651(4)$ & $0.0530(13)$ \\
\hline $\mathrm{C} 12$ & $0.4514(8)$ & $0.4419(5)$ & $0.6726(4)$ & 0.0726 (19) \\
\hline H12 & 0.3908 & 0.4882 & 0.7115 & $0.087 *$ \\
\hline $\mathrm{C} 13$ & $0.5642(9)$ & $0.3908(6)$ & $0.7213(5)$ & $0.082(2)$ \\
\hline H13 & 0.5807 & 0.4039 & 0.7931 & $0.098 *$ \\
\hline $\mathrm{C} 14$ & $0.6504(9)$ & $0.3224(6)$ & $0.6660(5)$ & $0.083(2)$ \\
\hline H14 & 0.7239 & 0.2857 & 0.7004 & $0.100 *$ \\
\hline $\mathrm{C} 15$ & $0.6313(7)$ & $0.3059(5)$ & $0.5591(4)$ & $0.0608(15)$ \\
\hline H15 & 0.6951 & 0.2617 & 0.5210 & $0.073 *$ \\
\hline H1 & $0.480(3)$ & $0.268(5)$ & $0.217(4)$ & $0.051(16)^{*}$ \\
\hline
\end{tabular}


Atomic displacement parameters $\left(\AA^{2}\right)$

\begin{tabular}{lllllll}
\hline & $U^{11}$ & $U^{22}$ & $U^{33}$ & $U^{12}$ & $U^{13}$ & $U^{23}$ \\
\hline Br1 & $0.0673(3)$ & $0.0624(3)$ & $0.0669(3)$ & $0.0056(3)$ & $0.0118(6)$ & $-0.0006(3)$ \\
O1 & $0.0301(18)$ & $0.111(3)$ & $0.049(2)$ & $0.006(2)$ & $-0.0069(16)$ & $0.001(2)$ \\
N1 & $0.033(2)$ & $0.061(3)$ & $0.035(2)$ & $-0.001(2)$ & $-0.0091(19)$ & $-0.003(2)$ \\
N2 & $0.045(3)$ & $0.058(3)$ & $0.035(2)$ & $0.000(2)$ & $-0.009(2)$ & $-0.002(2)$ \\
C1 & $0.035(2)$ & $0.049(3)$ & $0.033(2)$ & $-0.004(2)$ & $0.001(2)$ & $0.003(2)$ \\
C2 & $0.046(3)$ & $0.058(3)$ & $0.055(4)$ & $0.011(2)$ & $0.003(3)$ & $0.006(3)$ \\
C3 & $0.067(4)$ & $0.059(3)$ & $0.063(4)$ & $0.002(3)$ & $0.008(3)$ & $-0.008(3)$ \\
C4 & $0.061(3)$ & $0.062(3)$ & $0.041(3)$ & $-0.013(3)$ & $0.005(3)$ & $-0.007(3)$ \\
C5 & $0.052(3)$ & $0.066(3)$ & $0.040(3)$ & $-0.001(3)$ & $-0.013(2)$ & $-0.001(3)$ \\
C6 & $0.038(2)$ & $0.055(3)$ & $0.041(2)$ & $0.0026(19)$ & $-0.005(3)$ & $-0.003(3)$ \\
C7 & $0.097(4)$ & $0.095(5)$ & $0.058(3)$ & $-0.016(6)$ & $-0.009(3)$ & $-0.021(5)$ \\
C8 & $0.029(2)$ & $0.059(3)$ & $0.040(3)$ & $-0.003(2)$ & $0.000(2)$ & $0.008(2)$ \\
C9 & $0.049(3)$ & $0.046(3)$ & $0.039(3)$ & $-0.003(2)$ & $-0.013(2)$ & $-0.002(2)$ \\
C10 & $0.057(3)$ & $0.041(2)$ & $0.033(2)$ & $-0.008(2)$ & $-0.006(3)$ & $-0.002(3)$ \\
C11 & $0.070(4)$ & $0.045(3)$ & $0.043(3)$ & $-0.014(3)$ & $0.000(3)$ & $-0.002(2)$ \\
C12 & $0.116(6)$ & $0.059(4)$ & $0.042(4)$ & $-0.021(4)$ & $0.016(4)$ & $-0.006(3)$ \\
C13 & $0.152(7)$ & $0.059(4)$ & $0.034(3)$ & $-0.030(4)$ & $-0.021(4)$ & $-0.003(3)$ \\
C14 & $0.117(6)$ & $0.082(5)$ & $0.050(4)$ & $-0.001(5)$ & $-0.043(4)$ & $0.002(4)$ \\
C15 & $0.075(4)$ & $0.054(3)$ & $0.053(3)$ & $-0.002(3)$ & $-0.020(3)$ & $0.003(3)$ \\
& & & & & & \\
\hline
\end{tabular}

Geometric parameters $\left(A,{ }^{\circ}\right)$

\begin{tabular}{llll}
\hline $\mathrm{Br} 1-\mathrm{C} 11$ & $1.891(6)$ & $\mathrm{C} 6-\mathrm{H} 6$ & 0.9300 \\
$\mathrm{O} 1-\mathrm{C} 8$ & $1.225(6)$ & $\mathrm{C} 7-\mathrm{H} 7 \mathrm{C}$ & 0.9600 \\
$\mathrm{~N} 1-\mathrm{C} 8$ & $1.351(6)$ & $\mathrm{C} 7-\mathrm{H} 7 \mathrm{~A}$ & 0.9600 \\
$\mathrm{~N} 1-\mathrm{N} 2$ & $1.379(5)$ & $\mathrm{C} 7-\mathrm{H} 7 \mathrm{~B}$ & 0.9600 \\
$\mathrm{~N} 1-\mathrm{H} 1$ & $0.837(19)$ & $\mathrm{C} 9-\mathrm{C} 10$ & $1.470(8)$ \\
$\mathrm{N} 2-\mathrm{C} 9$ & $1.270(6)$ & $\mathrm{C} 9-\mathrm{H} 9$ & 0.9300 \\
$\mathrm{C} 1-\mathrm{C} 2$ & $1.375(7)$ & $\mathrm{C} 10-\mathrm{C} 11$ & $1.381(7)$ \\
$\mathrm{C} 1-\mathrm{C} 6$ & $1.389(6)$ & $\mathrm{C} 10-\mathrm{C} 15$ & $1.386(7)$ \\
$\mathrm{C} 1-\mathrm{C} 8$ & $1.485(6)$ & $\mathrm{C} 11-\mathrm{C} 12$ & $1.385(7)$ \\
$\mathrm{C} 2-\mathrm{C} 3$ & $1.375(8)$ & $\mathrm{C} 12-\mathrm{C} 13$ & $1.378(10)$ \\
$\mathrm{C} 2-\mathrm{H} 2$ & 0.9300 & $\mathrm{C} 12-\mathrm{H} 12$ & 0.9300 \\
$\mathrm{C} 3-\mathrm{C} 4$ & $1.371(8)$ & $\mathrm{C} 13-\mathrm{C} 14$ & $1.340(10)$ \\
$\mathrm{C} 3-\mathrm{H} 3$ & 0.9300 & $\mathrm{C} 13-\mathrm{H} 13$ & 0.9300 \\
$\mathrm{C} 4-\mathrm{C} 5$ & $1.386(7)$ & $\mathrm{C} 14-\mathrm{C} 15$ & $1.370(8)$ \\
$\mathrm{C} 4-\mathrm{C} 7$ & $1.508(9)$ & $\mathrm{C} 14-\mathrm{H} 14$ & 0.9300 \\
$\mathrm{C} 5-\mathrm{C} 6$ & $1.384(8)$ & $\mathrm{C} 15-\mathrm{H} 15$ & \\
$\mathrm{C} 5-\mathrm{H} 5$ & 0.9300 & & 10900 \\
& & & 109.5 \\
$\mathrm{C} 8-\mathrm{N} 1-\mathrm{N} 2$ & $119.2(4)$ & $\mathrm{H} 7 \mathrm{C}-\mathrm{C} 7-\mathrm{H} 7 \mathrm{~B}$ & $121.7(4)$ \\
$\mathrm{C} 8-\mathrm{N} 1-\mathrm{H} 1$ & $123(4)$ & $\mathrm{H} 7 \mathrm{~A}-\mathrm{C} 7-\mathrm{H} 7 \mathrm{~B}$ & $121.6(4)$ \\
$\mathrm{N} 2-\mathrm{N} 1-\mathrm{H} 1$ & $117(4)$ & $\mathrm{O} 1-\mathrm{C} 8-\mathrm{N} 1$ & $116.6(4)$ \\
$\mathrm{C} 9-\mathrm{N} 2-\mathrm{N} 1$ & $116.0(4)$ & $\mathrm{O} 1-\mathrm{C} 8-\mathrm{C} 1$ & $\mathrm{C} 8-\mathrm{C} 1$ \\
$\mathrm{C} 2-\mathrm{C} 1-\mathrm{C} 6$ & $118.6(5)$ & &
\end{tabular}




\begin{tabular}{|c|c|c|c|}
\hline $\mathrm{C} 2-\mathrm{C} 1-\mathrm{C} 8$ & $117.6(4)$ & $\mathrm{N} 2-\mathrm{C} 9-\mathrm{C} 10$ & $120.1(4)$ \\
\hline $\mathrm{C} 6-\mathrm{C} 1-\mathrm{C} 8$ & $123.8(5)$ & $\mathrm{N} 2-\mathrm{C} 9-\mathrm{H} 9$ & 120.0 \\
\hline $\mathrm{C} 1-\mathrm{C} 2-\mathrm{C} 3$ & $121.0(5)$ & $\mathrm{C} 10-\mathrm{C} 9-\mathrm{H} 9$ & 120.0 \\
\hline $\mathrm{C} 1-\mathrm{C} 2-\mathrm{H} 2$ & 119.5 & $\mathrm{C} 11-\mathrm{C} 10-\mathrm{C} 15$ & $118.1(5)$ \\
\hline $\mathrm{C} 3-\mathrm{C} 2-\mathrm{H} 2$ & 119.5 & $\mathrm{C} 11-\mathrm{C} 10-\mathrm{C} 9$ & $122.5(5)$ \\
\hline $\mathrm{C} 4-\mathrm{C} 3-\mathrm{C} 2$ & $121.2(5)$ & $\mathrm{C} 15-\mathrm{C} 10-\mathrm{C} 9$ & $119.4(5)$ \\
\hline $\mathrm{C} 4-\mathrm{C} 3-\mathrm{H} 3$ & 119.4 & $\mathrm{C} 10-\mathrm{C} 11-\mathrm{C} 12$ & $120.5(6)$ \\
\hline $\mathrm{C} 2-\mathrm{C} 3-\mathrm{H} 3$ & 119.4 & $\mathrm{C} 10-\mathrm{C} 11-\mathrm{Br} 1$ & $122.2(4)$ \\
\hline $\mathrm{C} 3-\mathrm{C} 4-\mathrm{C} 5$ & $118.2(5)$ & $\mathrm{C} 12-\mathrm{C} 11-\mathrm{Br} 1$ & $117.2(5)$ \\
\hline $\mathrm{C} 3-\mathrm{C} 4-\mathrm{C} 7$ & $121.8(6)$ & $\mathrm{C} 13-\mathrm{C} 12-\mathrm{C} 11$ & $119.4(6)$ \\
\hline $\mathrm{C} 5-\mathrm{C} 4-\mathrm{C} 7$ & $120.0(6)$ & $\mathrm{C} 13-\mathrm{C} 12-\mathrm{H} 12$ & 120.3 \\
\hline $\mathrm{C} 6-\mathrm{C} 5-\mathrm{C} 4$ & $121.1(5)$ & $\mathrm{C} 11-\mathrm{C} 12-\mathrm{H} 12$ & 120.3 \\
\hline $\mathrm{C} 6-\mathrm{C} 5-\mathrm{H} 5$ & 119.5 & $\mathrm{C} 14-\mathrm{C} 13-\mathrm{C} 12$ & $120.5(6)$ \\
\hline $\mathrm{C} 4-\mathrm{C} 5-\mathrm{H} 5$ & 119.5 & $\mathrm{C} 14-\mathrm{C} 13-\mathrm{H} 13$ & 119.8 \\
\hline $\mathrm{C} 5-\mathrm{C} 6-\mathrm{C} 1$ & $120.0(5)$ & $\mathrm{C} 12-\mathrm{C} 13-\mathrm{H} 13$ & 119.8 \\
\hline $\mathrm{C} 5-\mathrm{C} 6-\mathrm{H} 6$ & 120.0 & $\mathrm{C} 13-\mathrm{C} 14-\mathrm{C} 15$ & $120.6(7)$ \\
\hline $\mathrm{C} 1-\mathrm{C} 6-\mathrm{H} 6$ & 120.0 & $\mathrm{C} 13-\mathrm{C} 14-\mathrm{H} 14$ & 119.7 \\
\hline $\mathrm{C} 4-\mathrm{C} 7-\mathrm{H} 7 \mathrm{C}$ & 109.5 & $\mathrm{C} 15-\mathrm{C} 14-\mathrm{H} 14$ & 119.7 \\
\hline $\mathrm{C} 4-\mathrm{C} 7-\mathrm{H} 7 \mathrm{~A}$ & 109.5 & $\mathrm{C} 14-\mathrm{C} 15-\mathrm{C} 10$ & $120.8(6)$ \\
\hline $\mathrm{H} 7 \mathrm{C}-\mathrm{C} 7-\mathrm{H} 7 \mathrm{~A}$ & 109.5 & $\mathrm{C} 14-\mathrm{C} 15-\mathrm{H} 15$ & 119.6 \\
\hline $\mathrm{C} 4-\mathrm{C} 7-\mathrm{H} 7 \mathrm{~B}$ & 109.5 & $\mathrm{C} 10-\mathrm{C} 15-\mathrm{H} 15$ & 119.6 \\
\hline $\mathrm{C} 8-\mathrm{N} 1-\mathrm{N} 2-\mathrm{C} 9$ & $-173.3(5)$ & $\mathrm{C} 6-\mathrm{C} 1-\mathrm{C} 8-\mathrm{N} 1$ & $26.3(7)$ \\
\hline $\mathrm{C} 6-\mathrm{C} 1-\mathrm{C} 2-\mathrm{C} 3$ & $-1.5(7)$ & $\mathrm{N} 1-\mathrm{N} 2-\mathrm{C} 9-\mathrm{C} 10$ & $175.7(4)$ \\
\hline $\mathrm{C} 8-\mathrm{C} 1-\mathrm{C} 2-\mathrm{C} 3$ & $178.4(5)$ & $\mathrm{N} 2-\mathrm{C} 9-\mathrm{C} 10-\mathrm{C} 11$ & $161.4(5)$ \\
\hline $\mathrm{C} 1-\mathrm{C} 2-\mathrm{C} 3-\mathrm{C} 4$ & $1.0(8)$ & $\mathrm{N} 2-\mathrm{C} 9-\mathrm{C} 10-\mathrm{C} 15$ & $-19.2(7)$ \\
\hline $\mathrm{C} 2-\mathrm{C} 3-\mathrm{C} 4-\mathrm{C} 5$ & $-0.2(8)$ & $\mathrm{C} 15-\mathrm{C} 10-\mathrm{C} 11-\mathrm{C} 12$ & $-1.2(7)$ \\
\hline $\mathrm{C} 2-\mathrm{C} 3-\mathrm{C} 4-\mathrm{C} 7$ & $-179.2(6)$ & $\mathrm{C} 9-\mathrm{C} 10-\mathrm{C} 11-\mathrm{C} 12$ & $178.2(5)$ \\
\hline $\mathrm{C} 3-\mathrm{C} 4-\mathrm{C} 5-\mathrm{C} 6$ & $-0.1(8)$ & $\mathrm{C} 15-\mathrm{C} 10-\mathrm{C} 11-\mathrm{Br} 1$ & $178.1(4)$ \\
\hline $\mathrm{C} 7-\mathrm{C} 4-\mathrm{C} 5-\mathrm{C} 6$ & $178.9(6)$ & $\mathrm{C} 9-\mathrm{C} 10-\mathrm{C} 11-\mathrm{Br} 1$ & $-2.5(6)$ \\
\hline $\mathrm{C} 4-\mathrm{C} 5-\mathrm{C} 6-\mathrm{C} 1$ & $-0.3(8)$ & $\mathrm{C} 10-\mathrm{C} 11-\mathrm{C} 12-\mathrm{C} 13$ & $0.4(8)$ \\
\hline $\mathrm{C} 2-\mathrm{C} 1-\mathrm{C} 6-\mathrm{C} 5$ & $1.1(7)$ & $\mathrm{Br} 1-\mathrm{C} 11-\mathrm{C} 12-\mathrm{C} 13$ & $-178.9(5)$ \\
\hline $\mathrm{C} 8-\mathrm{C} 1-\mathrm{C} 6-\mathrm{C} 5$ & $-178.8(5)$ & $\mathrm{C} 11-\mathrm{C} 12-\mathrm{C} 13-\mathrm{C} 14$ & $-1.1(10)$ \\
\hline $\mathrm{N} 2-\mathrm{N} 1-\mathrm{C} 8-\mathrm{O} 1$ & $-3.5(7)$ & $\mathrm{C} 12-\mathrm{C} 13-\mathrm{C} 14-\mathrm{C} 15$ & $2.8(11)$ \\
\hline $\mathrm{N} 2-\mathrm{N} 1-\mathrm{C} 8-\mathrm{C} 1$ & $174.6(4)$ & $\mathrm{C} 13-\mathrm{C} 14-\mathrm{C} 15-\mathrm{C} 10$ & $-3.6(10)$ \\
\hline $\mathrm{C} 2-\mathrm{C} 1-\mathrm{C} 8-\mathrm{O} 1$ & $24.6(7)$ & $\mathrm{C} 11-\mathrm{C} 10-\mathrm{C} 15-\mathrm{C} 14$ & $2.8(8)$ \\
\hline $\mathrm{C} 6-\mathrm{C} 1-\mathrm{C} 8-\mathrm{O} 1$ & $-155.5(5)$ & $\mathrm{C} 9-\mathrm{C} 10-\mathrm{C} 15-\mathrm{C} 14$ & $-176.6(6)$ \\
\hline $\mathrm{C} 2-\mathrm{C} 1-\mathrm{C} 8-\mathrm{N} 1$ & $-153.6(5)$ & & \\
\hline
\end{tabular}

Hydrogen-bond geometry $\left(A,{ }^{\circ}\right)$

\begin{tabular}{lllll}
\hline$D-\mathrm{H} \cdots A$ & $D-\mathrm{H}$ & $\mathrm{H} \cdots A$ & $D \cdots A$ & $D-\mathrm{H} \cdots A$ \\
\hline $\mathrm{N} 1-\mathrm{H} 1 \cdots \mathrm{O} 1^{\mathrm{i}}$ & $0.84(3)$ & $1.96(3)$ & $2.785(5)$ & $167(5)$ \\
$\mathrm{C} 9-\mathrm{H} 9 \cdots \mathrm{O} 1^{\mathrm{i}}$ & 0.93 & 2.38 & $3.166(6)$ & 142 \\
\hline
\end{tabular}

Symmetry code: (i) $x-1 / 2,-y+1 / 2, z$. 